\title{
Asset Price Persistence and Real Estate Market Illiquidity: Evidence from Japanese Land Values
}

\author{
John Krainer ${ }^{\dagger}$ Mark M. Spiegel $^{\ddagger}$, and Nobuyoshi Yamori ${ }^{*}$
}

\begin{abstract}
We develop an overlapping generations model of the real estate market in which search frictions and a debt overhang combine to generate price persistence and illiquidity. Illiquidity stems from heterogeneity in agent real estate valuations. The variance of agent valuations determines how quickly prices adjust following a shock to fundamentals. We examine the predictions of the model by studying price depreciation in Japanese land values subsequent to the 1990 stock market crash. Commercial land values fell much more quickly than residential land values. As we would posit that the variance of buyer valuations would be greater for residential real estate than for commercial real estate, this model matches the Japanese experience.
\end{abstract}

Keywords: Debt overhang, illiquidity, price persistence, Japan, real estate

\author{
J.E.L. Classification No. G12, R31, R33 \\ ${ }^{\dagger}$ Federal Reserve Bank of San Francisco, 101 Market Street, San Francisco, CA, 94105,

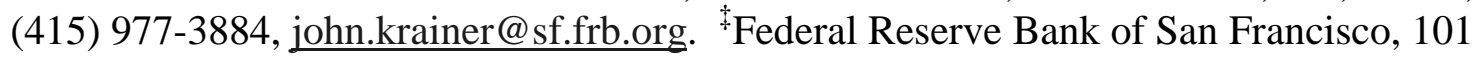 \\ Market Street, San Francisco, CA, 94105, (415)-974-3241, fax: (415)-974-2168, \\ mark.spiegel@sf.frb.org. *Nagoya University, Nagoya, Japan. We thank Robert \\ Marquez, Carlos Slawson and seminar participants at the Federal Reserve Bank of San \\ Francisco, Florida State University, and the AREUEA International Conference for \\ helpful comments. Edmund Chiang provided excellent research assistance. The views \\ expressed in this paper are our own and do not necessarily reflect those of the Federal \\ Reserve Bank of San Francisco or the Board of Governors of the Federal Reserve.
}




\section{Introduction}

In this paper we develop an asset pricing model based on search and a debt overhang problem in which equilibrium prices display persistence over time. We use the model to study transition dynamics in markets for illiquid assets such as land and real estate. We apply the basic insights of the model to analyze data on Japanese land prices in the wake of the stock market crash in that country in 1990.

Our working definition of asset liquidity is the equilibrium probability of sale. This definition encompasses the notion that illiquid assets are ones that can not be sold quickly at the equilibrium price. Search and illiquidity in our model arise from unobservable asset specificity, or the degree to which asset use and value depends on unobservable owner preferences. This seems natural in markets for land and real estate, where willingness-to-pay for a particular asset varies significantly across households and firms. All else held constant, increasing the heterogeneity of unobservable owner preferences leads to a decrease in the probability of asset sale in a single period.

Market illiquidity is necessary in our framework to generate slowly adjusting prices, but it is not sufficient. To generate sticky prices, we appeal to the fact that land and real estate purchases are usually financed. Shocks to the fundamental value of land destroy equity and create a debt overhang which needs to be worked off before the economy can converge to the new steady state. The novel feature of our model is that liquidity is the margin along which the debt overhang can be worked off. Sellers attempt to avoid default by keeping their prices above fundamental value—or the eventual steady state price-effectively "fishing" for high-valuation buyers. The speed of transition to the new steady state price depends upon the expected gains from fishing. In markets with 
a large degree of heterogeneity in preferences, large debt overhangs, or both, transition rates can be long even though all agents are forward looking and optimizing.

We investigate the validity of the model by examining the pattern of price depreciation in Japanese land values subsequent to the 1990 stock market crash. The Japanese case is natural to study because of the size of the shock to real estate markets. As we show below, all Japanese land values fell substantially subsequent to the crash. It is interesting to note, however, that commercial land values fell much more quickly (and farther) than residential land values. Below, we confirm this empirical fact using an error-correction model. We then argue that a reasonable interpretation of our model parameters generates this same difference in the speed of adjustment to shocks across different markets for land.

The theoretical literature on liquidity, as pertaining to real estate markets, has developed along two different paths. The first path of research reflects the original observation that illiquid markets were those where expected times to sale were long. As such, this line of research borrowed heavily from the search literature to model the real estate transaction. These models were used to explore, among other things, the determinants of the optimal vacancy rate, the optimal intensity of search (Wheaton (1992)), the properties of returns on illiquid assets (Krainer and LeRoy (2002) and Williams (1995)), and why liquidity can vary over the business cycle (Krainer (2001)).

A separate literature seeking to explain real estate price dynamics has developed around the observation that debt plays an important role in these markets. One of early papers in this literature was by Stein (1995). ${ }^{1}$ In Stein's model, homeowner's make

\footnotetext{
${ }^{1}$ Stein's paper is closely related to the fire sale literature in finance. See Shleifer and Vishny (1992). See also Kelly and LeRoy (2004) for a treatment of fire sales and liquidation that incorporates search.
} 
downpayments in order to finance their purchases. Small declines in prices can damage collateral values, which can lead to large effects on transaction volumes, as homeowners can not raise enough of a downpayment to enter the trade-up market. ${ }^{2}$ Genesove and Mayer (1997) verify empirically many of the features of Stein's model, finding that sellers with low (or negative) equity set relatively higher prices and take longer to sell their real estate assets.

Our model borrows from the search-based literature in that the search friction is the ultimate source of illiquidity. Our model differs from Stein's in that our main focus is not so much the fact that liquidity varies over different states of nature, but that prices adjust slowly following shocks. In our model, price persistence stems from the seller's outstanding debt burden, rather than from a downpayment constraints on future purchases. The debt burden distorts the selling decision because the seller's payoffs are invariant with respect to sales price in default states, which are more probable the larger is the debt burden relative to the mean house service flow. Additionally, our model is dynamic, which allows us to use the illiquidity attributable to debt overhangs to generate persistence in price declines subsequent to permanent decreases in asset service flows.

The dynamics in our model match empirical features that have been associated with deviations from rational behavior in the literature. For example, there is a large empirical literature documenting serial correlation and mean reversion in the housing market, including Case and Shiller (1989), Malpezzi (1999), and Capozza, et al. (2004). In the literature, serial correlation in housing markets has been explained through

\footnotetext{
${ }^{2}$ Kiyotaki and Moore (1996) use a similar mechanism to generate a financial role in exacerbating the volatility of business cycles.
} 
backward-looking expectations by market participants. In our paper, serial correlation in prices emerges under rational expectations.

Our model also matches stylized facts that have been associated with loss aversion in the literature, such as Genesove and Mayer (2001). Genesove and Mayer found that condominium owners subject to nominal losses charged prices exceeding the property's expected selling price and experienced greater illiquidity. In a sense, our model can also "rationalize" the phenomenon of loss aversion in housing on the basis of the debt overhang faced by property owners.

The paper is organized as follows. In section 2 we develop the model and analyze the transition from one steady state equilibrium to another. In section 3 we provide some background information on the Japanese land and real estate markets. In section 4 we present the empirical evidence from Japanese land prices in support of the implications of the model. Section 5 concludes the paper.

\section{A Theory of Liquidity and Debt Overhang}

\subsection{Setup}

The model is an overlapping generations model. There are $N$ agents born each period who live for two periods. Agents have risk neutral preferences for both consumption of housing services and consumption of consumption goods. Agents buy and consume housing services when young, and sell their houses to the next generation when old. ${ }^{3}$

\footnotetext{
${ }^{3}$ Our overlapping generations setup forces old agents to sell their house. In a more general framework, we might imagine that houses come on the market because their owners need to relocate for employment purposes, or need to adjust housing consumption because of changing family size.
} 
There are two frictions in the model. First, buyers are required to finance a portion of their house purchase. Accordingly, we assume the existence of a representative intermediary. For simplicity, we assume that the value of the real estate asset is sufficient to fully collateralize the house, so that the equilibrium interest rate is fixed. The intermediary repossesses the house in case default, and proceeds to liquidate the house in the open market at the market price. For simplicity we do not model this liquidation process. The intermediary's role is simply to create debt. This debt will turn out to have important implications for asset prices following unexpected shocks to fundamentals.

The second friction in the model is that houses are bought and sold following a search process. Each period, a buyer is paired randomly with a house. The buyer's valuation of the house will depend on two things: the value to the buyer of the service flow, and the expected payoff to reselling the house in the next period. A buyer's valuation of the service flow is a draw from a distribution.

We interpret the mean of this distribution as the state variable determined by the aggregate economy. For example, the level of interest rates, the pace of economic growth, or some special amenity to a geographic area, would be expected to represent "fundamentals" that are captured in all house prices. As these variables change, all prices and all valuations are expected to follow. We interpret variation about the mean of the service flow distribution as being related to individual tastes. Specifically, we will characterize residential housing as an asset with substantial variation about the mean valuation of the service flow. The best matched buyer will value a particular house much 
higher than the average buyer. We will characterize commercial real estate as an asset with relatively little variation in valuation across potential buyers.

The realization of the service flow is the buyer's private information, while the seller knows only the distribution. ${ }^{4}$ Sellers set take-it-or-leave-it prices. If a buyer chooses not to purchase the house, he rents the house instead, paying out an amount equal in expected value to his service flow from renting. ${ }^{5}$ That is, renting is a breakeven proposition.

Proceeding more formally, let $\varepsilon$ be the service flow draw, and let $\varepsilon$ be distributed according to c.d.f. $F$. Buyers must make a down payment equal to $\gamma$-percent of the asking price. ${ }^{6}$ Faced with a house price $p_{t}$, a realization of the housing service flow $\varepsilon$, and the discounted expected proceeds from sale of the house next period $\beta q_{t+1}$, the potential buyer will buy if and only if,

$$
\gamma p_{t} \leq \beta q_{t+1}+\mathcal{\varepsilon}
$$

where $\beta$ is representative agent's discount factor $(0<\beta \leq 1)$. The value of the service flow, $\varepsilon_{t}^{*}$, that makes (1) hold with equality is the reservation service flow. This will be an important definition, as our measure of liquidity will be the probability of sale, or the probability that an agent draws a service flow of at least $\varepsilon_{t}^{*}$.

Given the distribution of the service flow for potential buyers and given the amount of debt the seller is carrying, the seller sets a price in order to maximize the

\footnotetext{
${ }^{4}$ Note that private information held by young agents allows them to retain some consumer surplus in this framework.

${ }^{5}$ The buyer is actually renting from the bank. If a buyer refuses to buy, the seller defaults.

${ }^{6} \mathrm{We}$ abstract away from endowments of a consumption good, assuming that preferences are both linear and separable in consumption and housing consumption.
} 
expected value of having a house on the market. Since agents only consume housing services in the first period of life, sellers in the second period are completely homogeneous.

The seller's decision problem is then to choose a price $p_{t}$ that maximizes the expected proceeds of selling the house given his outstanding debt level, $d_{t}$, or

$$
\begin{aligned}
& q_{t}=\max _{\tilde{p}} \mu_{t}(\tilde{p})\left(\tilde{p}-d_{t}\right) \\
& d_{t} \geq 0,
\end{aligned}
$$

where $\mu(p)$ is the probability of sale at price $p$. This yields his first order condition

$$
\frac{\partial \mu_{t}}{\partial p_{t}}\left(p_{t}-d_{t}\right)+\mu_{t}=0
$$

The probability of sale is the probability the buyer draws a service flow at least as great as the reservation service flow, $\varepsilon^{*}$. From (1), this yields

$$
\mu_{t}=1-F\left(\gamma p_{t}-\beta q_{t+1}\right)
$$

For the special case where $\varepsilon$ is distributed uniform on the interval $\left[\bar{\varepsilon}_{t}-\sigma, \bar{\varepsilon}_{t}+\sigma\right]$, we get

$$
\mu_{t}=\frac{\bar{\varepsilon}_{t}+\sigma-\gamma p_{t}+\beta q_{t+1}}{2 \sigma}
$$

Since $q_{t+1}$ will be chosen optimally in the following period, we obtain an envelope result, which implies that the partial derivative of $\mu_{t}$ with respect to $p_{t}$ satisfies

$$
\frac{\partial \mu_{t}}{\partial p_{t}}=\frac{1}{2 \sigma}\left[-\gamma+\beta \frac{\partial q_{t+1}}{\partial d_{t+1}} \frac{\partial d_{t+1}}{\partial p_{t}}\right] .
$$

To close the model, we must determine the value of $d_{t}$. The representative bank that charges a fixed interest rate times the amount borrowed, or 


$$
d_{t+1}=R(1-\gamma) p_{t}
$$

so that (6) now satisfies

$$
\frac{\partial \mu_{t}}{\partial p_{t}}=-\frac{\gamma+\beta R(1-\gamma) \mu_{t+1}}{2 \sigma}
$$

Given an initial debt level, $d_{l}$, equilibrium is a set of sequences $\left\{p_{t}, q_{t}, \mu_{t}, d_{t}\right\}_{t=1}^{\infty}$ that satisfy equations (2), (3), (5), and (7) for all $t$, where $\frac{\partial \mu_{t}}{\partial p_{t}}$ in (3) is given by equation (8). The equilibrium is a Nash equilibrium, and in general will not be first best. ${ }^{7}$ This is due to the search friction and the heterogeneity in the model. At any point in time, a social planner could reallocate members of the young generation into houses they prefer more, thereby granting all of the young generation a consumer surplus and increasing aggregate welfare.

\subsection{Analysis of the steady state}

From this simple model we can derive some comparative statics results for pricing and liquidity. First, consider a seller at some date $t$, who has a given amount of outstanding debt $d_{t}$ which is predetermined. By equations (4) and (6), it is easy to show that the optimal (interior solution) value of $p_{t}$ is increasing in $d_{t}$. In other words, the magnitude of the seller's debt overhang distorts the selling price upwards. However, if the interior solution violates the constraint, the optimum will be $p_{t}=d_{t}$. It is also easy to show that the number of unsold houses $N\left(1-\mu_{t}\right)$, is also increasing in $d_{t}$.

\footnotetext{
${ }^{7}$ In the appendix we establish conditions for the existence of a steady state equilibrium with positive prices.
} 
Second, we would expect greater variance in the distribution of housing service flows to translate into higher prices and less liquidity. This would certainly be the case for an individual seller at some time $t$ taking $d_{t}$ as given, as can be seen by inspection from equations (4) and (6). The intuition behind these results is that the outstanding debt reduces the net profits from selling the house. Sellers facing heterogeneous buyers have the incentive to price their houses higher, essentially "fishing" for high-valuation buyers. This is particularly true when they are saddled with a debt overhang.

To obtain the comparative statics of our steady state relationships, we simulate steady state solutions for a range of parameters. As we can see in Figure 1, prices are increasing in the heterogeneity parameter $\sigma$. As the distribution of the service flow widens, sellers find it optimal to sell to an increasingly higher-valuation buyer. The magnitude of this result will, of course, depend on the mean service flow, $\bar{\varepsilon}$. If the variance is very small about the mean, the effect of small increases in variance on prices will be negligible. Correspondingly, the figure also shows that probability of sale is decreasing in the heterogeneity parameter. This is intuitive, given our earlier result that $\frac{\partial p}{\partial \sigma}>0$. Higher prices imply lower probability of sale or less liquidity.

Figure 2 depicts simulations of the steady state solutions as we vary the mean service flow parameter. As we can see, higher mean service flows are accompanied by both higher prices and higher probabilities of sale, all else held equal. Intuitively, an increase in the mean service flow raises all potential buyer valuations ex ante. But prices do not rise as high as they might, as evidenced by the fact that the probability of sale does not remain constant. This is because the variance parameter of the service flow distribution is being held fixed in these simulations. As the mean value increases, the 
difference between the best matched individual's valuation and the average valuation diminishes in percentage terms. This implies a reduction in the seller's incentive to fish for high-value buyers.

Two main points emerge from our analysis of the steady state. First, holding the mean service flow fixed, assets with a large amount of dispersion in potential buyer valuations will be higher priced and less liquid. Given our belief that residential housing is an asset for which buyers display a wide distribution of willingness-to-pay, residential housing should be less liquid than commercial property. Second, prices are sensitive to changes in the mean service flow. Over time, then, we would expect that variation in prices is determined by variation in the mean service flow. Moreover, the more liquid the asset, the more volatile prices should be with respect to shocks to mean service flows or fundamentals. We make this point more precisely when we study the dynamics of the model in the next section.

\subsection{Transition in a multi-period model}

Our analysis of the steady state is useful for establishing the basic implications of debt and heterogeneity for prices and liquidity. However, important questions cannot be answered without dynamics. For example, given a debt overhang, how sticky will prices be? That is, how long will it take for prices to adjust following a shock to the steady state? In this section we develop a dynamic extension to the simple model that analyzes the transition of the economy following a shock to debt levels. This exercise serves to motivate the empirical work to follow on the behavior of the Japanese land prices after the bursting of the stock market bubble. The high prices and debt levels associated with 
the bubble period, and the bursting of this bubble is interpreted as an exogenous shock. Conversely, we could imagine that the economy was in equilibrium for some relatively high value of the mean housing service flow, and was suddenly thrown out of that steady state by a change to a lower mean housing service flow. The object, in either case, is to study the transition to the new steady state. ${ }^{8}$

We simulate transition between steady states associated with mean service flow values $\bar{\varepsilon}=1$ and $\bar{\varepsilon}=.5$. We assume agents make down payments equal to $\gamma=20 \%$ of the purchase price. The discount rate is $\beta=0.97$. For purposes of comparison, we assume that both residential and commercial real estate have the same mean service flow. We represent residential real estate by a large variance about the mean service flow, $\sigma=1.5$, and commercial real estate by a small variance about the mean, $\sigma=1$.

Figure 3 plots the dynamic response of prices to a once-and-for-all change in the fundamental (the mean service flow). Both asset classes do not adjust immediately to the new steady state value. Rather, prices decline gradually to their new steady state levels. This is because of the debt overhang. Agents who bought houses when $\bar{\varepsilon}=1$, find themselves carrying more debt than the new steady state associated with $\bar{\varepsilon}=.5$ implies. The economy does not instantly adjust to the new steady state price because such an adjustment would be inconsistent with the optimization rules of the sellers who have too much debt. The economy can adjust gradually by virtue of the search friction. The agents with the highest debt overhang relative to the new steady state keep prices high in the hopes of making a match with a high valuation buyer. This is akin to raising the price, so the probability of sale must fall.

\footnotetext{
${ }^{8}$ The focus in this paper is on transition from a high price state of the world to a low price state. In the model, however, the debt overhang affects price dynamics when prices are increasing as well. These simulations are available from the authors upon request.
} 
Asset liquidity plummets in the early stages of the transition (see Figure 4), but then slowly improves as the price converges to the new steady state. As such, our model exhibits overshooting in the decline in liquidity subsequent to the decline in the fundamental. Overall, the new steady state is at a lower liquidity level. This is because with a lower mean service flow, the variance about the mean is proportionally larger, and the desire to fish for a high valuation buyer is greater.

Figure 4 also shows differences in the adjustment process between the residential and the commercial asset. The low service flow variance asset price falls farther between the two steady states. This implies that prices of the low variance asset are more volatile given the same service flow shocks.

We next turn to the Japanese experience following the collapse of the asset price bubble in the beginning of the 1990s. We examine the pattern of price persistence following the collapse for commercial and residential real estate values. As we would identify the low variance service flow asset with Japanese commercial real estate, our model would predicts that commercial prices should fall farther and faster than residential prices. Using data on Japanese land values, we demonstrate that the Japanese experience matches these properties of the model. ${ }^{9}$

\section{Background Information on the Japanese Land and Real Estate Market}

\subsection{General features of the Japanese real estate market}

Before examining the adjustment pattern of Japanese land prices following the stock market crash, it is useful to give some background information. Overall, housing ownership rates in Japan are quite similar to those in other developed countries. The

\footnotetext{
${ }^{9}$ Kan, Kwong, and Leung (2002) document this same stylized fact in the U.S.
} 
latest survey data for the incidence of ownership in Japanese residential real estate is available from the Statistics Bureau of the Ministry of Public Management, Home Affairs, Posts and Telecommunications for $1998 .{ }^{10}$ Nationally, the incidence of real estate ownership in 1998 stood at 60.3 percent, somewhat lower than the ownership rate of about $65 \%$ in the United States. The rate is lower in the urban Keihinyo metropolitan area, which includes Tokyo, Yokohama, Chiba and Saitama, at 52.3 percent, and in the Keihanshin metropolitan area, which includes Osaka, Kyoto, and Kobe, at 56.1 percent. However, the Chukyo metropolitan area, which includes Nagoya, is slightly higher than the national average at 56.1 percent.

One unique feature of the Japanese real estate market is the relatively high share of down payments made on housing purchases. On average, Japanese households make down payments equal to about 30 percent of purchase prices. The need to self-finance this relatively large down-payment is often cited as a major contributor to high rates of savings among young Japanese households. For example, housing related expenditures have been found to provide the primary non-precautionary motivation for saving [Horioka (1988)]. Combined with proceeds from sales of currently-owned real estate and inheritances from relatives, the share of self-financing in housing is about 43 percent [Seko (1994)]. ${ }^{11}$ In an overlapping generations framework, Hayashi, Ito and Slemrod (1988) show that high down payments such as those found in Japan can increase the rate of savings when young in an effort to meet their self-financing needs. Indeed, the high

\footnotetext{
${ }^{10}$ The survey, known as the "Housing and Land Statistical Research" (Jyutaku-Tochi Toukei Chosa in Japanese) has been conducted every five years since 1948. The latest survey was done in 2003, but the results have not yet been released.

${ }^{11}$ Reported figure represents annual average for custom-made housing from 1984 through 1989.
} 
down payment required for housing is often identified as a key reason behind Japan's high savings rate [e.g. Hayashi (1986)].

As of 2001, Japanese individuals held 85.5 percent of land holdings and corporations held 14.5 percent. Holdings by corporations were higher in large cities, as individuals held only 71.3 percent of land and corporations held 28.7 percent. Land ownership by individuals has fallen steadily since 1980, according to the Ministry of Land, Infrastructure and Transport (see Figure 5). ${ }^{12}$ This data is only available at irregular intervals, but clearly shows a notable decline in ownership by individuals between 1987 and 1993. This pattern suggests that defaults on real estate loans played a role in moving land assets from individuals to corporations after the end of the asset bubble period.

Finally, another unique aspect of Japanese housing is the relatively small market for used homes. The number of used house transactions per household in Japan in 1992 was one-tenth that in the United States in the same year [Kanemoto (1997)]. Kanemoto stresses the high costs of housing transactions in Japan as a primary reason for the low turnover rate. Housing transactions are subject to a series of taxes that total about 2 percent of housing value, as well as a capital gains tax. In addition, in the early 1990s subsidized loans from the Government Housing Loan Corporation discriminated against used housing by placing a lower limit on the absolute value of loans to used housing and by prohibiting lending to used housing exceeding ten years in age.

\footnotetext{
${ }^{12}$ Source: Ministry of Land, Infrastructure and Transport White Paper on Land (Tochi Hakusho in Japanese).
} 


\subsection{Real estate price movements after the bubble collapse}

We next turn to the stylized data concerning the severity of the Japanese real estate downturn. The Japanese government has almost solely published land value data for some period of time. We use this land data in the main portion of our study. As discussed by Noguchi (1994), land price movements account for the bulk of movements in urban housing costs, comprising over 90 percent of housing costs in Tokyo and Osaka, and over 60 percent in all urban areas.

Price data on structures is available, but at a lower frequency. The Urban Development Association (Toshi-Kaihatsu Kyokai in Japanese) collects average prices of new single-family homes (excluding condominiums) for the Tokyo, Osaka and Nagoya metropolitan areas. See Figure 6. Housing prices peak between 1990 and 1991, with the Osaka region peaking in 1990 and the Tokyo and Nagoya regions peaking in 1991, and falling dramatically thereafter. Note that there is a slow decline subsequent to the asset price collapse suggestive of price rigidity that mirrors the land price series.

One sees a similar impact on condominium prices. Data on condominium prices are available beginning in 1992 for the nation as a whole, as well as the Tokyo and Osaka Ward districts from the Real Estate Economic Institute (Fudosan-Keizai-Kenkyusho). See Figure 7. There is again evidence of price persistence for the Japanese condominium market, as prices continued to fall until 1995 , after which the market was relatively flat.

Weakness in the housing market appears to have been a primary factor behind the well-documented difficulties suffered by the Japanese banking sector during the 1990s. Exposure to real estate companies was increased dramatically during the bubble period, 
from approximately 7 percent before the period to about 11.5 percent by December 1989. ${ }^{13}$ Some authors, such as Hoshi (2001), attribute the high growth in the share of real estate lending within the banking sector to a decline in alternative lending opportunities due to deregulation in the financial sector which allowed traditional borrowers, such as corporate clients, to issue their own commercial paper and reduce their bank borrowing.

\subsection{Summary}

Our review of the characteristics of the Japanese housing market identifies some important stylized facts surrounding the collapse of the Japanese real estate bubble. First, we find evidence of rigidity in Japanese real estate prices. While Japanese real estate prices fell dramatically throughout the 1990s, the price declines continue long after the 1991-1992 shock. Second, there was clearly an interaction between developments in the Japanese housing market and those in the Japanese banking sector: Declines in Japanese real estate values eroded bank collateral positions. These effects were particularly severe because of the buildup in the banking system of exposure to the real estate sector. Throughout the downturn, Japanese banks suffered, and those with higher exposure to real estate suffered more.

However, the causality also ran the other way. Real estate owners holding mortgages obtained prior to the burst of the asset price bubble faced reduced, and perhaps even negative, equity in their assets. The influence of this debt overhang is shown below to play a central role in obtaining the price rigidity observed in the data.

\footnotetext{
${ }^{13}$ Bank of Japan.
} 


\section{Empirical Evidence Concerning Japanese Land Values}

\subsection{Data}

Quarterly data on changes in residential and commercial land prices are available from 1993:2 through 2003:1 from the Land Research Institute (LRI) for the Tokyo, Osaka, and Nagoya metropolitan areas. The data on land prices is plotted in logs in Figure 8. It can be seen that land prices fell dramatically over this period in all three areas. However, two stylized facts appear to emerge in the patterns of relative price declines of residential and commercial real estate in each area: First, commercial land prices fell much more dramatically than residential prices. In Tokyo, Osaka and Nagoya, residential land prices fell by 41.4 percent, 42.7 percent, and 29.1 percent respectively over the sample period, while commercial land prices fell 72.3 percent, 73.8 percent, and 64.0 percent respectively.

Summary statistics for both the quarterly metropolitan and annual prefecture data sets are shown in Table 2. Looking first at the quarterly data, it can be seen that both residential and commercial land prices peaked in the second quarter of 1993. Both forms of land prices also fell throughout the sample, reaching their minimums on the last quarter of our sample, the first quarter of 2003. Commercial land prices are much more volatile than residential land prices for all three metropolitan areas, as measured by the ratio of the standard deviations of the series to their mean values. Finally, it appears that both commercial and residential land prices fell the least in the Nagoya metropolitan area and the furthest in the Osaka metropolitan area. The data also demonstrate that the 
standard deviations of commercial land prices in all three metropolitan areas are substantially larger than those of the residential land price series.

Moreover, it appears to be the case that the fall in commercial prices was more rapid than that for real estate prices. For example, by the midpoint of our sample period Tokyo residential prices had fallen by 21.9 percent, slightly more than half of their ultimate 41.5 percent decline over the course of the sample period. In contrast, by the same date, Tokyo commercial real estate prices had fallen by 57.1 percent, which represented more than three-fourths of their 72.3 percent decline over the entire sample period. Similarly, by the midpoint of our sample period, residential land prices in Osaka and Nagoya had fallen by only 17.4 percent and 16.1 percent respectively, less than half of their decline over the entire sample period, while their commercial land prices had fallen by 52.2 percent and 42.4 percent respectively, both over two-thirds of their ultimate declines over the entire sample period.

As our quarterly data only goes back to 1993 , we also obtain annual prefecture data from the Research on Land Prices by the Prefecture Government to examine the runup in land values prior to the bursting of the bubble. This data is available annually for each of the 47 prefectures on July 1, from 1976 to 2001 . We therefore have 26 price observations for each prefecture, for a total of 1222 observations for each series.

The summary statistics for these series are also listed in Table 2. The long time series in the data implies that minimum values for residential and commercial land values were realized in the early portion of the sample, in 1976 and 1979 respectively for residential and commercial land. Land values in our prefecture data also peaked earlier than our metropolitan time series, as residential and commercial real estate values peaked 
in 1990 and 1991 respectively. Commercial land values again exhibit greater volatility, with the ratio of the standard deviation to the mean of the pooled commercial land value sample being almost twice the size of that for the pooled residential land value sample. As above, the prefecture data demonstrate that the standard deviation of commercial land prices is much larger than that of the residential land prices.

Log averages of the prefecture data are plotted in Figure 9. The commercial land prices can again be seen to be significantly more volatile than the residential or industrial land prices. For example, we can compare the speed of decline in these averages following their peaks in the early 1990s. The residential price averages peaked in 1990, while the commercial price averages peaked in 1991. By 1996, residential prices fell by 27.9 percent, 71.5 percent of its 39.0 percent overall price decline. By the same date (which represented one less year of elapsed time), commercial prices fell by 58.0 percent, 78.1 percent of its 74.3 percent price decline by the end of our sample. ${ }^{14}$

\subsection{Error-correction Model}

To examine these empirical patterns more formally, we turn to an error-correction model. In his study of housing prices, Malpezzi (1999) estimates an error-corection model using income as the co-integrating variable with housing prices. While income would appear to be a desirable co-integrating variable, it does not appear to work well for Japan, particularly in our quarterly data. The reason is that while Japanese asset values clearly peaked in 1990 or 1991, as evidenced by the rapid subsequent declines in housing and equity market prices in Figure 9, average household income across prefectures in Japan actually continued to modestly rise until 1997. This is in part attributable to

\footnotetext{
${ }^{14}$ If we use 1991 as our starting year for residential prices as well, the results are similar.
} 
lifetime employment traditions and other characteristics that are unique to the Japanese economy, as well as the slow adjustment that took place in Japanese firms subsequent to the bursting of the Japanese asset price bubble.

For our purposes, however, it suggests that much longer time series than those available would be needed to identify the co-integrating relationship between house prices and income in Japan. In particular, it is unlikely that we could identify any discernable pattern for the ten-year period in our sample subsequent to the boom. In response, we instead turn to a forward-looking indicator of real estate service flows, namely equity values proxied by the TOPIX index. Figure 5 demonstrates that there has been a close correlation between both commercial and residential real estate since the 1970s, which allows us to examine the speed of adjustment both upwards and downwards.

Our error-correction equation then describes movements in land prices, $P_{t}$ towards its equilibrium long-run ratio with the value of Japanese equities as measured by the TOPIX. We entertain variants of the general specification

$$
\begin{aligned}
\Delta P_{t} & =\beta_{0}+\beta_{1} \Delta P_{t-1}+\ldots+\beta_{n} \Delta P_{t-n} \\
& +\theta_{1} \Delta \text { TOPIX }_{t-1}+\ldots+\theta_{n} \Delta \text { TOPIX } \\
& +\gamma_{1-n}\left(P_{t-1}-\text { TOPIX }_{t-1}\right)+\ldots+\gamma_{n}\left(P_{t-1}-\text { TOPIX }_{t-1}\right)+\varepsilon_{t}
\end{aligned}
$$

where $\varepsilon_{t}$ is assumed to be an i.i.d. error term.

In particular, we expect to obtain negative coefficients on the error correction terms, the $\gamma_{i}{ }^{\prime} s$. This would imply that if house prices lie above their equilibrium level they will fall, while they rise if they are above their equilibrium levels. The coefficients on these terms therefore describe the speed with which land prices revert back to their 
long-run equilibrium relationship with the TOPIX after being shocked away from that relationship.

Quarterly results for residential and commercial land prices from the three metropolitan areas are reported in Tables $3 \mathrm{a}$ and $3 \mathrm{~b}$. We estimate a number of different specifications to assess the robustness of our results, with one and two lags of the $\Delta P_{t}$, $\Delta$ TOPIX $_{t}$, and $\left(P_{t-1}-\right.$ TOPIX $\left._{t-1}\right)$ variables. The latter variable is of course the one of interest representing the error-correction term. ${ }^{15}$

As we are relatively agnostic about the ideal specification, we also include panel Durbin-Watson statistics [Bhargava, et al (1982)] to assess the severity of serial correlation in the various reported specifications. The results suggest that for our quarterly data, the null of no serial correlation is rejected for models 1,4 , and 5, and accepted for models 2, 3, 6, and 7. No models fell into the "inconclusive range", which tends to be relatively small in panel studies. As such, we concentrate our discussion on the latter group of models, although we report our results for all of them for completeness.

Comparing the commercial and residential results reveals some interesting stylized facts. First, in both samples the coefficient on the first lag error-correction term is universally negative and significant for all specifications passing the serial correlation test. Second, regardless of the specification chosen, the negative error-correction term is substantially larger in absolute value for the commercial sample than for the residential

\footnotetext{
${ }^{15} \mathrm{We}$ also ran the specification with the addition of a third lag for all of the specifications. The coefficient sign on the third lag was of inconsistent sign and did not always enter positively in both samples. Consequently, we restricted our analysis to those with up to two lags presented here.
} 
sample. The results therefore support the hypothesis that commercial land prices revert back to their long run levels more quickly than residential land prices.

Examining the other variables in our specification, we obtain some other results. For both samples, the coefficient on $\Delta P_{t}$ is positive and significant at a five percent confidence level. Moreover, the coefficient for the commercial sample is uniformly smaller than that for the residential sample. Again, these results suggest that residential land prices are more persistent than commercial land prices in Japan.

The coefficient estimates on the contemporaneous and lagged $\triangle T O P I X_{t}$ variables are almost universally insignificant. However, we do robustly obtain a significant positive point estimate on the NAGOYA dummy variable, confirming our observation above that land prices fell less in Nagoya than in the other two metropolitan areas.

Our annual results using prefecture data for commercial and residential land prices are reported in Tables $4 \mathrm{a}$ and $4 \mathrm{~b}$. Our results with this data set are qualitatively similar to those for the quarterly data set. The same set of specifications, models $2,3,6$, and 7, pass the serial correlation test, and we concentrate our discussion on those models. The coefficient estimate on the error-correction term is robustly negative in both samples, with the exception of Model 6 for the residential sample, where the second-lag errorcorrection term is added. Both terms remain significantly negative in this model for the commercial sample.

Most importantly, we again obtain point estimates on the error-correction terms that are universally larger in absolute value in the commercial sample than those we obtain in the residential sample. Moreover, because our sample is much larger, the disparity in coefficient estimates is robustly different at standard significance levels. For 
all of the specifications that do not include a second lag of the error-correction term, Models 1, 2, 3, 5, and 7, the coefficient on the first lag error-correction term is significantly larger in absolute value for the commercial land sample than the residential land sample. For the two models that introduce the second lag, the more negative coefficient is again larger in both specifications for the commercial sample. This turns out to be the first lag in Model 4, but the second lag in model 6.

As before, we robustly obtain positive and significant coefficient estimates on the first lag of $\Delta P_{t}$. However, the point estimates for this coefficient are smaller in the case of the residential sample, so this variable does not provide additional evidence of greater relative price persistence in the residential sample, as we found in our quarterly data sample.

Nevertheless, the robust results for the error-correction terms in the two samples consistently indicate that the commercial land prices converge to their long-run equilibrium relationship with the TOPIX more quickly than residential land prices.

\section{Conclusion}

In this paper, we develop an overlapping-generations model with two-sided matching and search to explain why prices in illiquid markets display persistence. In our model, old agents are matched in each period with a young agent endowed with an idiosyncratic service value from the old agent's real estate asset. When fundamentals

decline, the old agent optimally "fishes" for a young agent who would obtain a high service flow from the asset by pricing above-average agent valuations. This leads to 
higher illiquidity and default in times of price declines, as well as persistence in price declines which is increasing in the variance of average service flows.

We explore the main predictions of the model using land price data from Japan. Subsequent to the collapse of stock prices in Japan in 1990, both commercial and residential real estate values fell dramatically. However, as our data and parametric results above demonstrated, commercial prices fell farther and more rapidly than residential prices. As we would posit that the variance of service flows would be higher for residential real estate than for the commercial real estate market, this model matches the Japanese experience. 


\section{APPENDIX}

Existence of the steady-state solution

By (7), in the steady state, $d$ satisfies

$$
d=R(1-\gamma) p
$$

Substituting for $d$ in (5), the steady state representation of $\mu$ satisfies

$$
2 \sigma \mu=(\bar{\varepsilon}+\sigma)-\gamma p+[1-R(1-\gamma)] \beta \mu p
$$

By (8), the steady state representation of the seller's first-order condition (3)

satisfies

$$
p=\frac{1}{2}\left\{d+\frac{\bar{\varepsilon}+\sigma+\beta \mu p}{\gamma+\beta R(1-\gamma) \mu}\right\}
$$

Substituting for $d$ we obtain

$$
2 \gamma[1-R(1-\gamma)] p=(\bar{\varepsilon}+\sigma)+\{1-2 R(1-\gamma)[1-R(1-\gamma)]\} \beta \mu p
$$

Combining

$$
\mu=\frac{[2 R(1-\gamma)-1][R(1-\gamma)(\bar{\varepsilon}+\sigma)-\gamma p]}{2 \sigma\{1-2 R(1-\gamma)[1-R(1-\gamma)]\}}
$$

Substituting into the equation for $p$

$\beta[2 R(1-\gamma)-1] \gamma p^{2}+\{4 \sigma \gamma[1-R(1-\gamma)]-\beta[2 R(1-\gamma)-1] R(1-\gamma)(\bar{\varepsilon}+\sigma)\} p-2 \sigma(\bar{\varepsilon}+\sigma)=0$

The solution for $p$ satisfies

$$
\begin{aligned}
& -\{4 \sigma \gamma[1-R(1-\gamma)]-\beta[2 R(1-\gamma)-1] R(1-\gamma)(\bar{\varepsilon}+\sigma)\}
\end{aligned}
$$

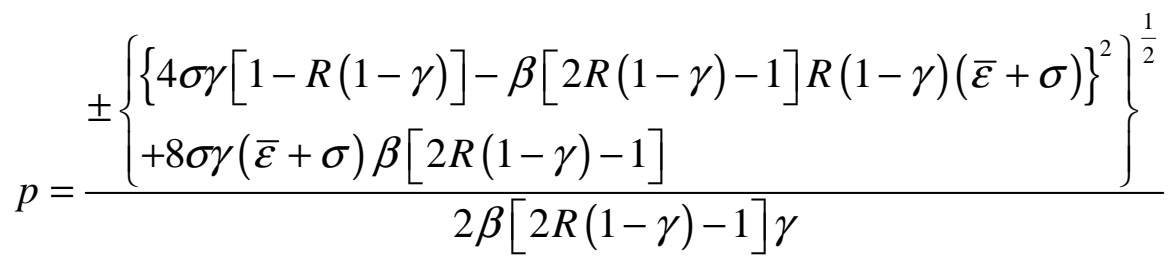


Simplifying,

$$
\begin{gathered}
\pm\left\{\begin{array}{l}
\{4 \sigma \gamma[1-R(1-\gamma)]-\beta[2 R(1-\gamma)-1] R(1-\gamma)(\bar{\varepsilon}+\sigma)\} \\
+8 \sigma \gamma(\bar{\varepsilon}+\sigma) \beta[2 R(1-\gamma)-1]\{1-R(1-\gamma)[1-R(1-\gamma)]\}
\end{array}\right\} \\
p=\frac{(1-\gamma)]\}^{2}+\{\beta[2 R(1-\gamma)-1] R(1-\gamma)(\bar{\varepsilon}+\sigma)\}^{2}}{2 \beta[2 R(1-\gamma)-1] \gamma}
\end{gathered}
$$

It can be seen by inspection that a sufficient, but not necessary condition for existence of a positive solution for $p$ is

$$
1 \geq R(1-\gamma) \geq \frac{1}{2}
$$

which leaves the term under the radical unambiguously positive, and implies a positive value for $p$ when taking the positive root. 


\section{References}

Case, K.E. and R. E. Shiller, 1989. "The Efficiency of the Market for Single Family Homes," American Economic Review. 79: 125-137.

Capozza, D. R., P. H. Hendershott, and C. Mack, 2004. "An Anatomy of Price Dynamics in Illiquid Markets: Analysis and Evidence from Local Housing Markets." Real Estate Economics. 32(1): 1-32.

Genesove, D., and Mayer, C., 1997. "Equity and Time-to-Sale in the Real Estate Market." American Economic Review. 87: 255-269.

Genesove, D., and Mayer, C., 2001. "Loss Aversion and Seller Behavior: Evidence from the Housing Market," N.B.E.R. Working Paper No. 8143, March.

Hayashi, F., 1986, “Why is Japan's Savings Rate so Apparently High?,” NBER Macroeconomics Annual, MIT Press, Cambridge, 147-210.

Hayashi, F., T. Ito, and J. Slemrod, 1988, "Housing Finance Imperfections, Taxation, and Private Saving: A Comparative Simulation Analysis of the United States and Japan, Journal of the Japanese and International Economies, 2(3), 215-238.

Horioka, C. Y., 1988, "Saving for Housing Purchase in Japan," Journal of the Japanese and International Economies, 2(3), 351-384.

Hoshi, T., 2001. "What Happened to Japanese Banks?" Monetary and Economic Studies, February, 1-29.

Kan, K., Kwong S., and Leung, C., 2002. "The Dynamics and Volatility of Commercial and Residential Property Prices: Theory and Evidence." Chinese University of Hong Kong working paper.

Kanemoto, Y., 1997. "The Housing Question in Japan.” Regional Science and Urban Economics. 27: 613-641.

Kelly, D., and LeRoy, S., 2003. "Liquidity and Liquidation.” Working paper, University of California at Santa Barbara.

Kiyotaki, N. and Moore, J., 1996. “Credit Cycles.” Journal of Political Economy. 105, 211-248.

Krainer, J., 2001. "A Theory of Liquidity in Residential Real Estate Markets." Journal of Urban Economics. 49: 32-53. 
Krainer, J., and LeRoy, S., 2002. "Equilibrium Valuation of Illiquid Assets." Economic Theory. 19: 223-242.

Lamont, O., and Stein, J., 1999. "Leverage and House Price Dynamics in U.S. Cities." RAND Journal of Economics, 30(3), Autumn, 498-514.

Malpezzi, S., 1999. "A Simple Error Correction Model of House Prices." Journal of Housing Economics. 8: 27-62.

Noguchi, Y.,1994, "Land Prices and House Prices in Japan," in Y. Noguchi and J. Poterba eds., Housing Markets in the United States and Japan, National Bureau of Economic Research, University of Chicago Press, Chicago, 11-28.

Seko, M., 1994, "Housing Finance in Japan," in Y. Noguchi and J. Poterba eds., Housing Markets in the United States and Japan, National Bureau of Economic Research, University of Chicago Press, Chicago, 49-64.

Shleifer, A., and Vishny, R., 1992. "Liquidation Values and Debt Capacity." Journal of Finance. 47: 1343-1366.

Stein, J., 1995. "Prices and Trading Volume in the Housing Market: A Model with Downpayment Effects." Quarterly Journal of Economics. 110: 379-406.

Wheaton, W., 1990. "Vacancy, Search, and Prices in a Housing Market Matching Model." Journal of Political Economy. 98: 1270-1292.

Williams, J., 1995. "Pricing Real Assets with Costly Search.” Review of Financial Studies. 8: 55-90. 
Figure 1

\section{Price and Probability of Sale as Function of Service Flow Variance}

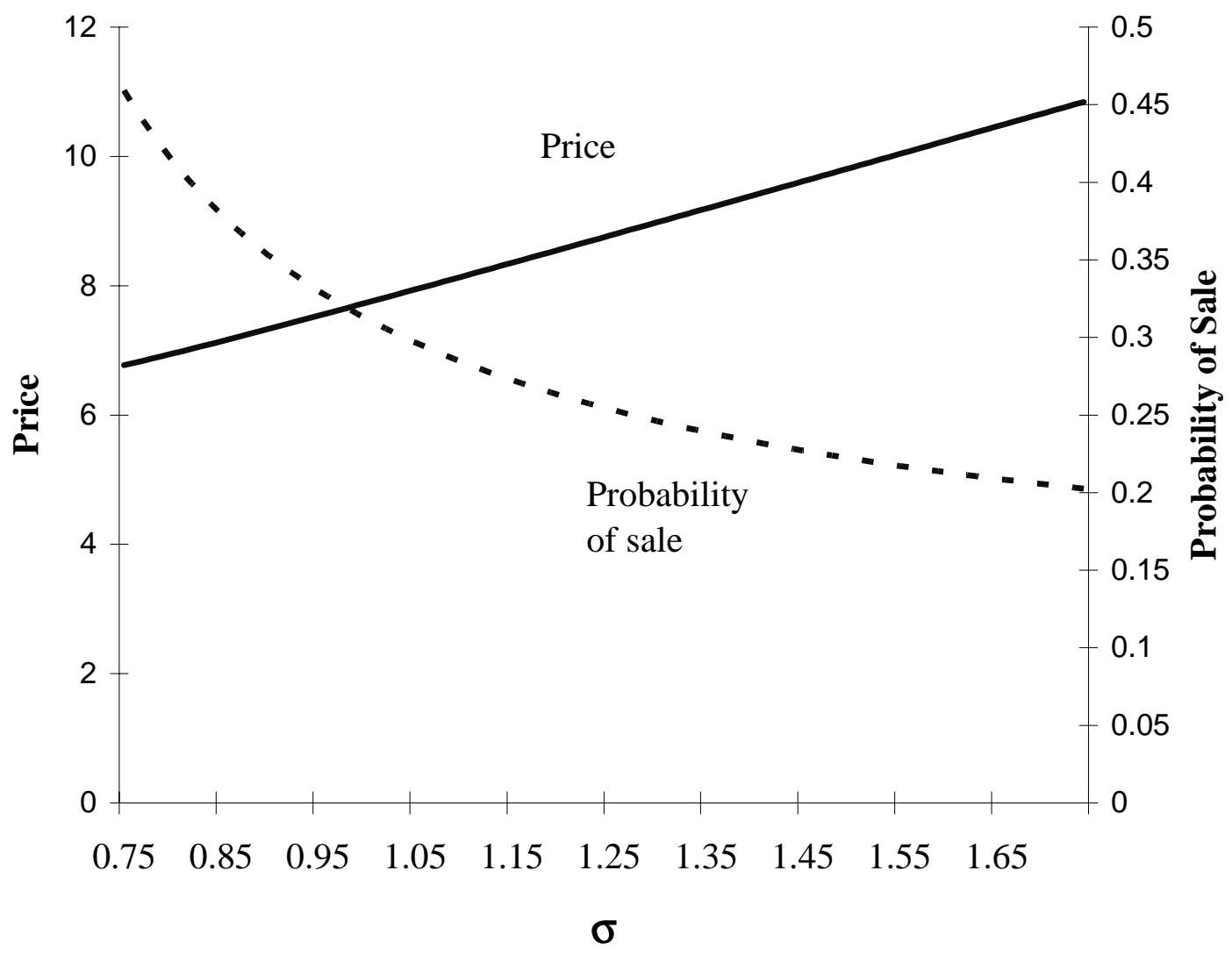

Notes: Steady-state solution for price, $p$, and probability of sale $\mu$ as a function of service flow variance, $\sigma$. Mean service flow fixed at .75. Downpayment rate is $20 \%$. Interest rate is $2.5 \%$ 


\section{Figure 2}

\section{Prices and Probabilities of Sale as Function of Mean Service Flow Value}

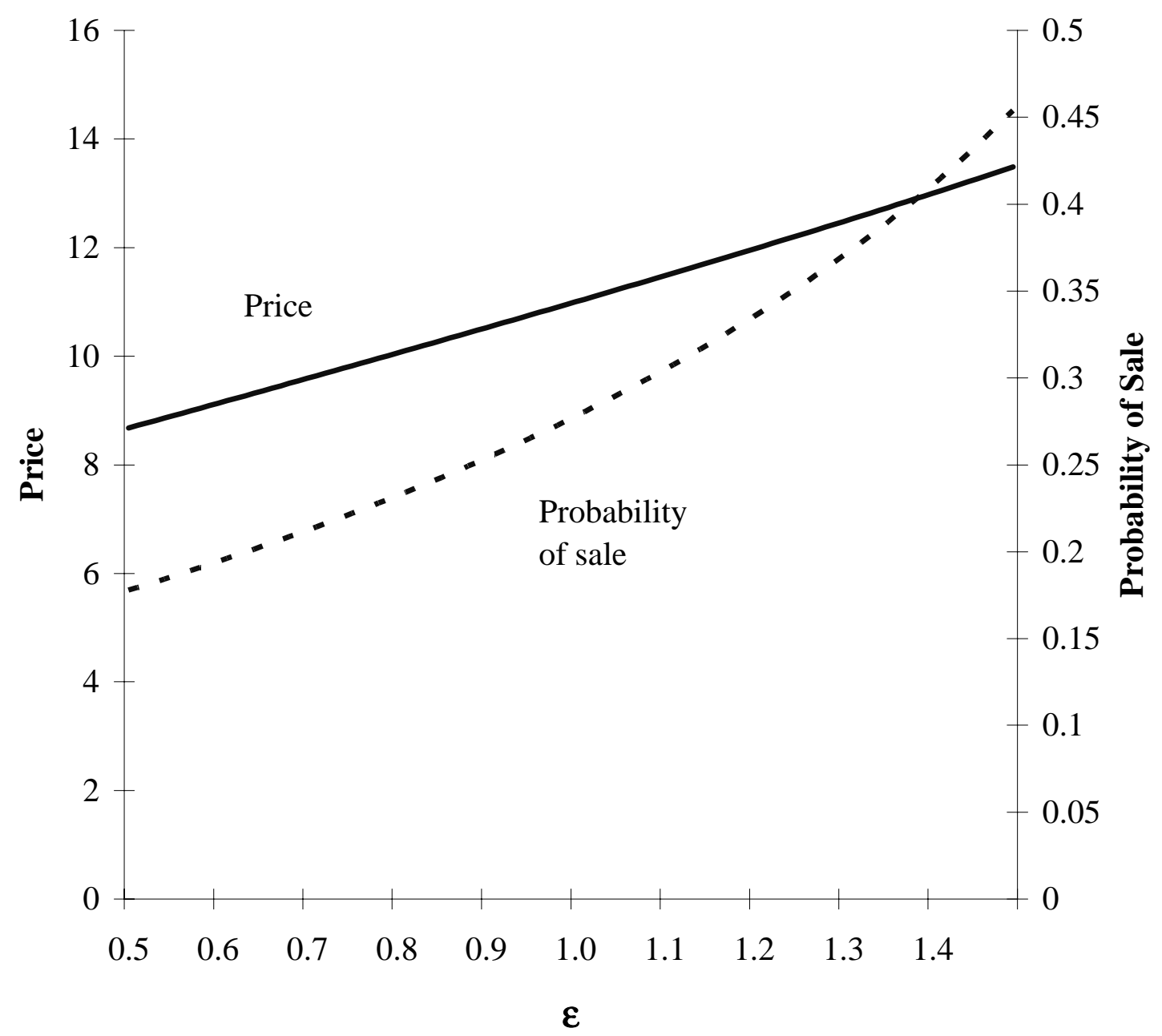

Notes: Steady-state solution for price, $p$, and probability of sale $\mu$ as a function of mean service flow, $\bar{\varepsilon}$. Variance of service flow fixed at 1.5. Downpayment rate is $20 \%$. Interest rate is $2.5 \%$ 


\section{Figure 3}

\section{Transition Path for Prices}

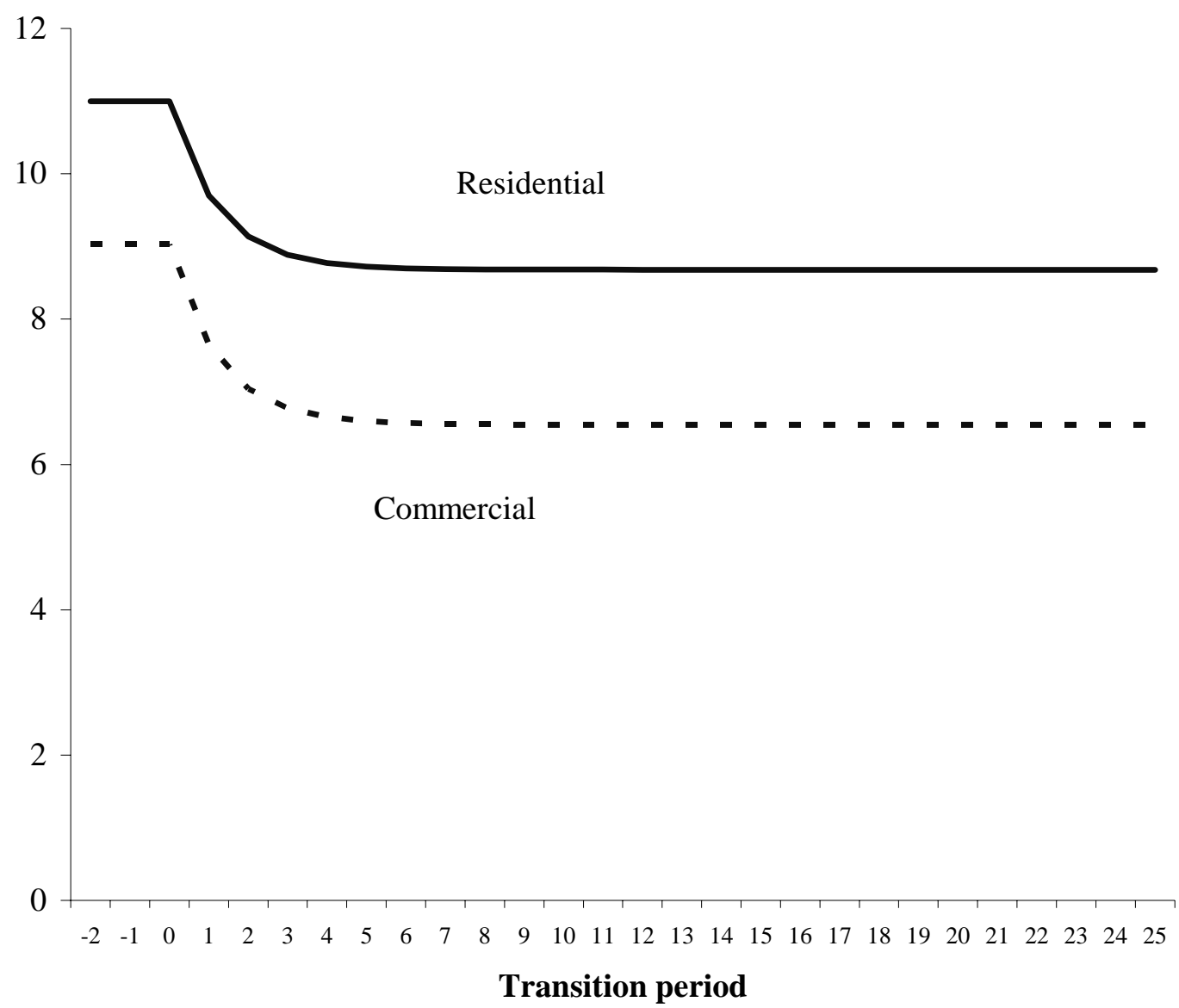

Notes: Figure depicts price dynamics following a once-and-for-all decline in the mean service flow, $\bar{\varepsilon}$, from 1 to .5 . We plot time series for high value of $\sigma=1.5$ (residential) and low value of $\sigma=1$ (commercial real estate). Other parameter values include the downpayment rate $(20 \%)$ and the mortgage interest rate $(2.5 \%)$. We allow the economy to adjust for 20 periods from the time of the initial shock in period 0 . 


\section{Figure 4}

\section{Transition Path for Probability of Sale}

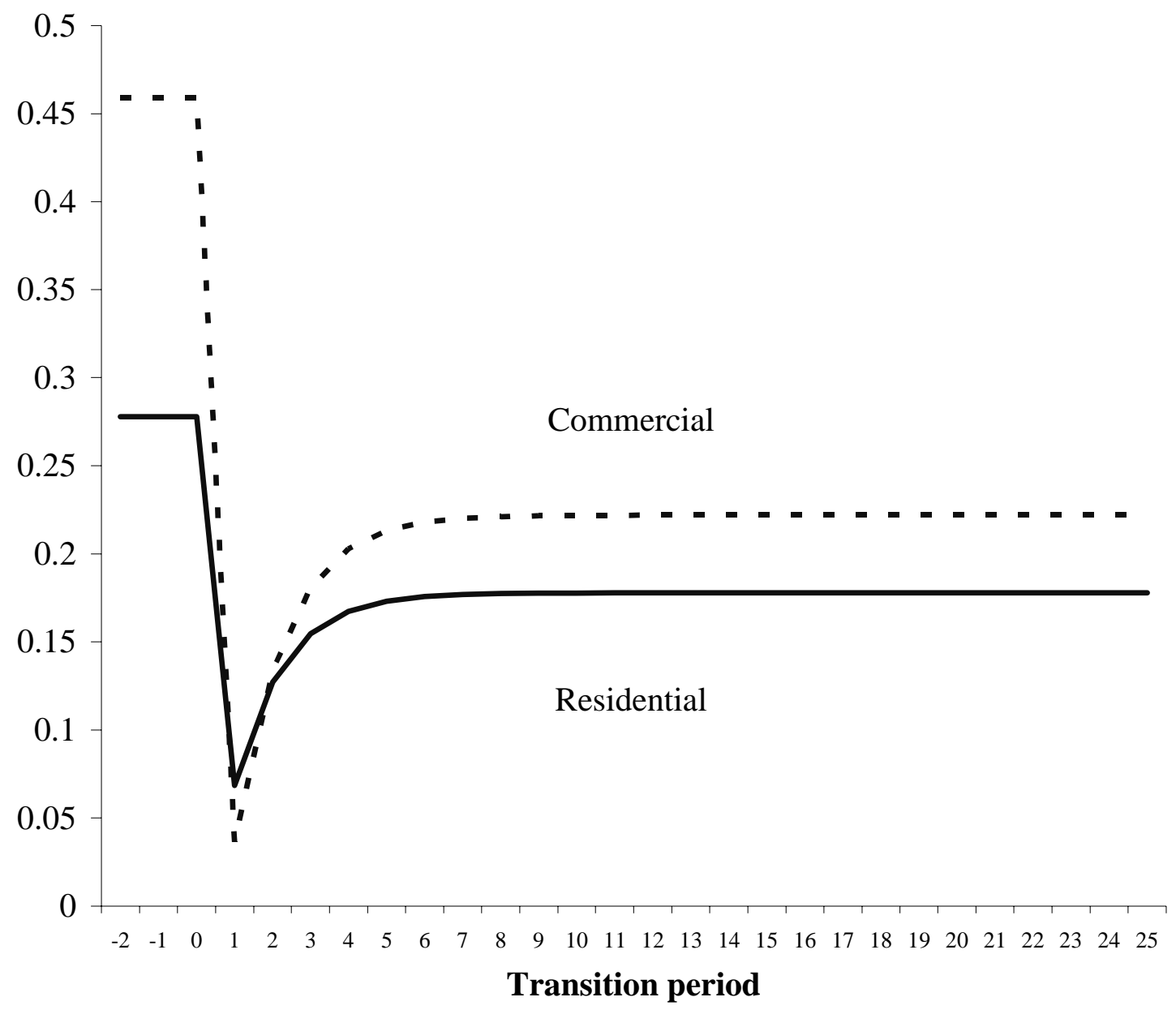

Notes: Figure depicts price dynamics following a once-and-for-all decline in the mean service flow, $\bar{\varepsilon}$, from 1 to .5 . Other parameter values include the downpayment rate $(20 \%)$ and the mortgage interest rate $(2.5 \%)$. We allow the economy to adjust for 20 periods from the time of the initial shock in period 0 . We plot time series for high value of $\sigma=1.5$ (residential real estate) and low value of $\sigma=1.0$ (commercial real estate). Under both values, there is an initial steep drop in sale probability, resulting in some amount of overshooting, followed by a persistent increase in sale probabilities until they reach their steady-state values. 


\section{Figure 5}

\section{Share of Japanese Land Ownership by Individuals}

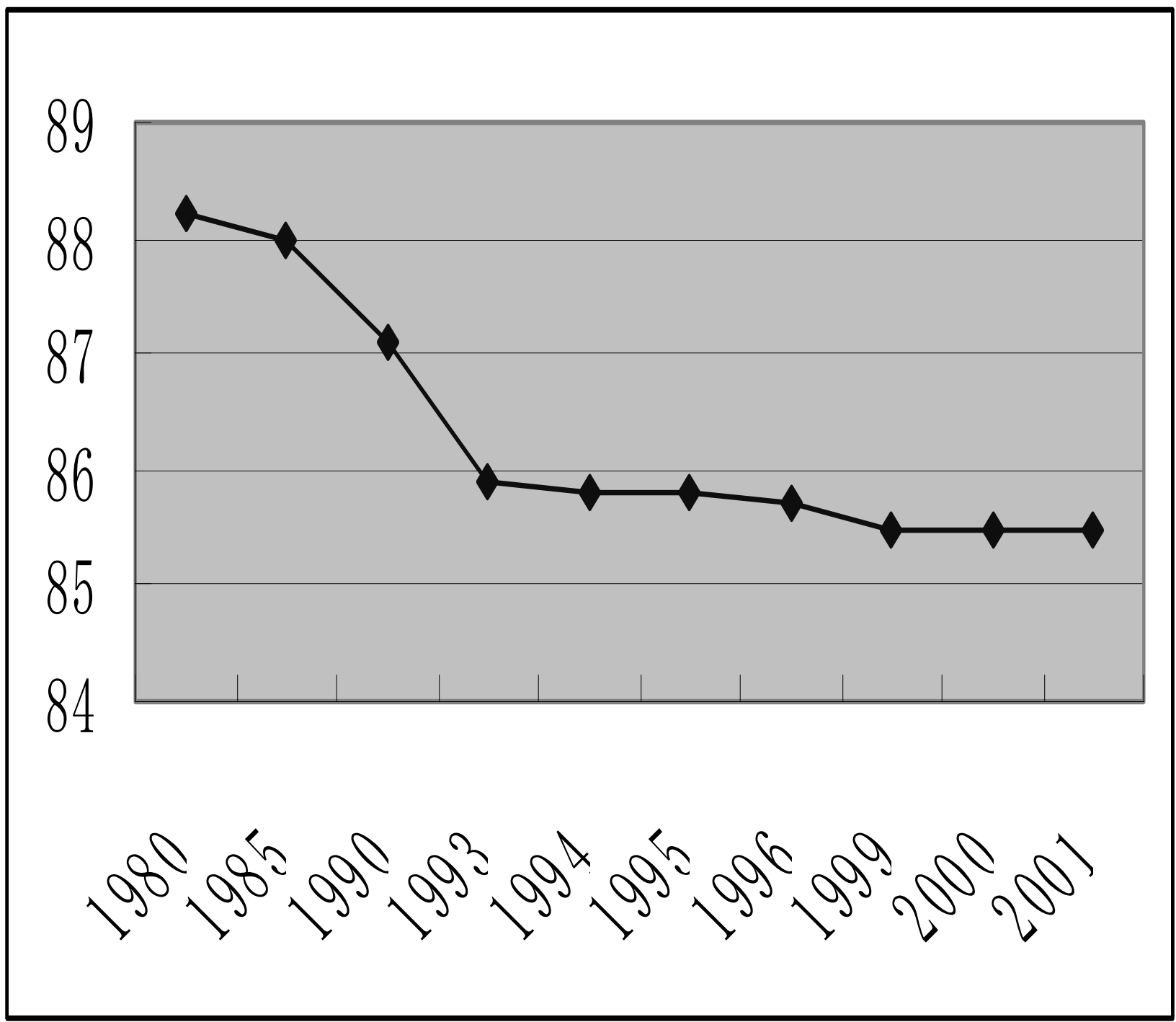

Notes: Percentage of land owned by individuals, rather than corporations. Source: Ministry of Land, Infrastructure and Transport White Paper on Land (Tochi Hakusho in Japanese). 


\section{Figure 6}

\section{House Prices for Tokyo, Osaka and Nagoya \\ (1986-2000)}

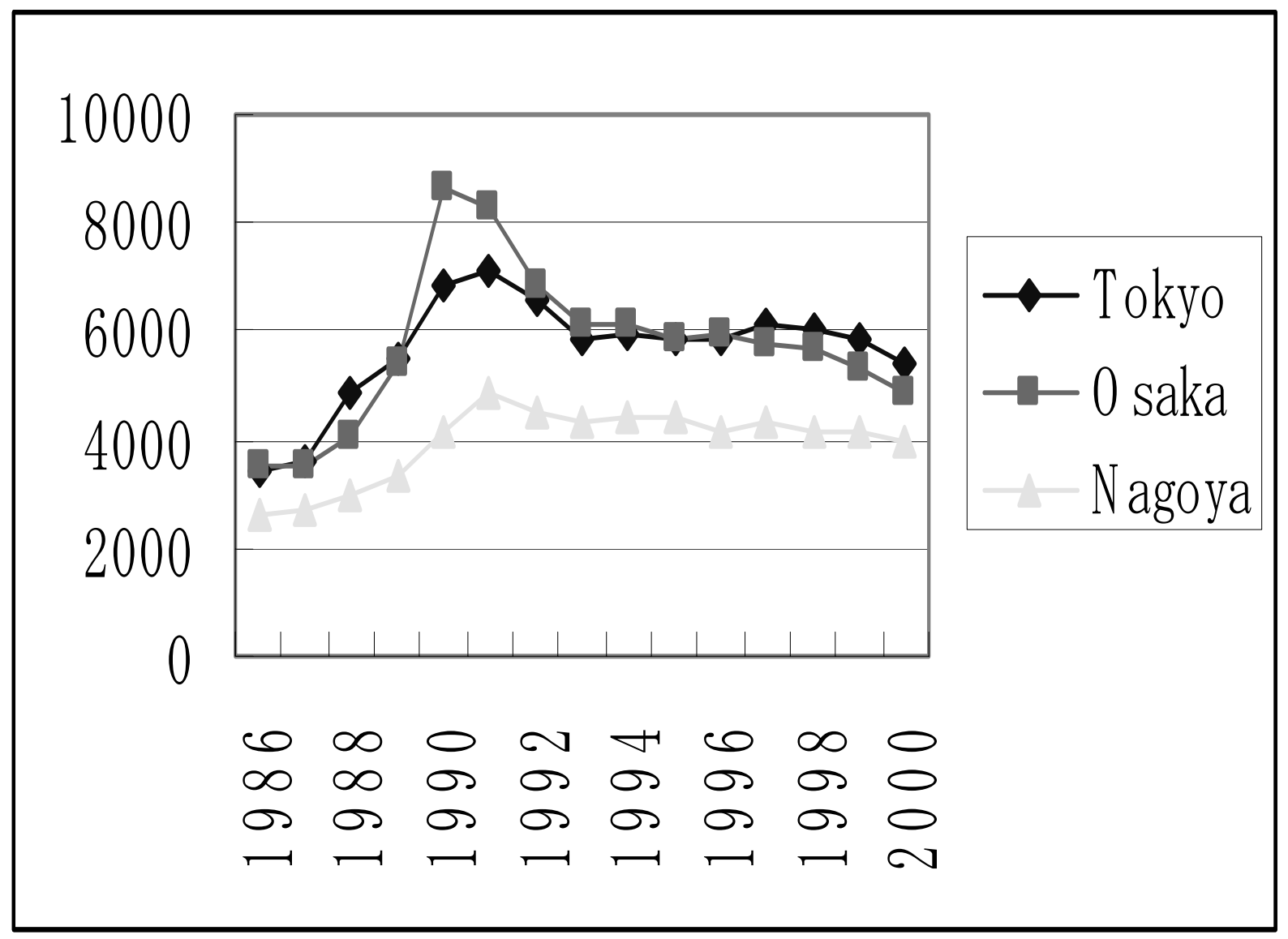

Notes: Figures are in ten-thousand yen. Average prices of new single-family houses (excluding condominiums) for the Tokyo, Osaka and Nagoya metropolitan areas. Source: Urban Development Association (Toshi-Kaihatsu Kyokai in Japanese). 


\section{Figure 7}

\section{Condominium Prices For Nation, Tokyo, and Osaka (1992-2001)}

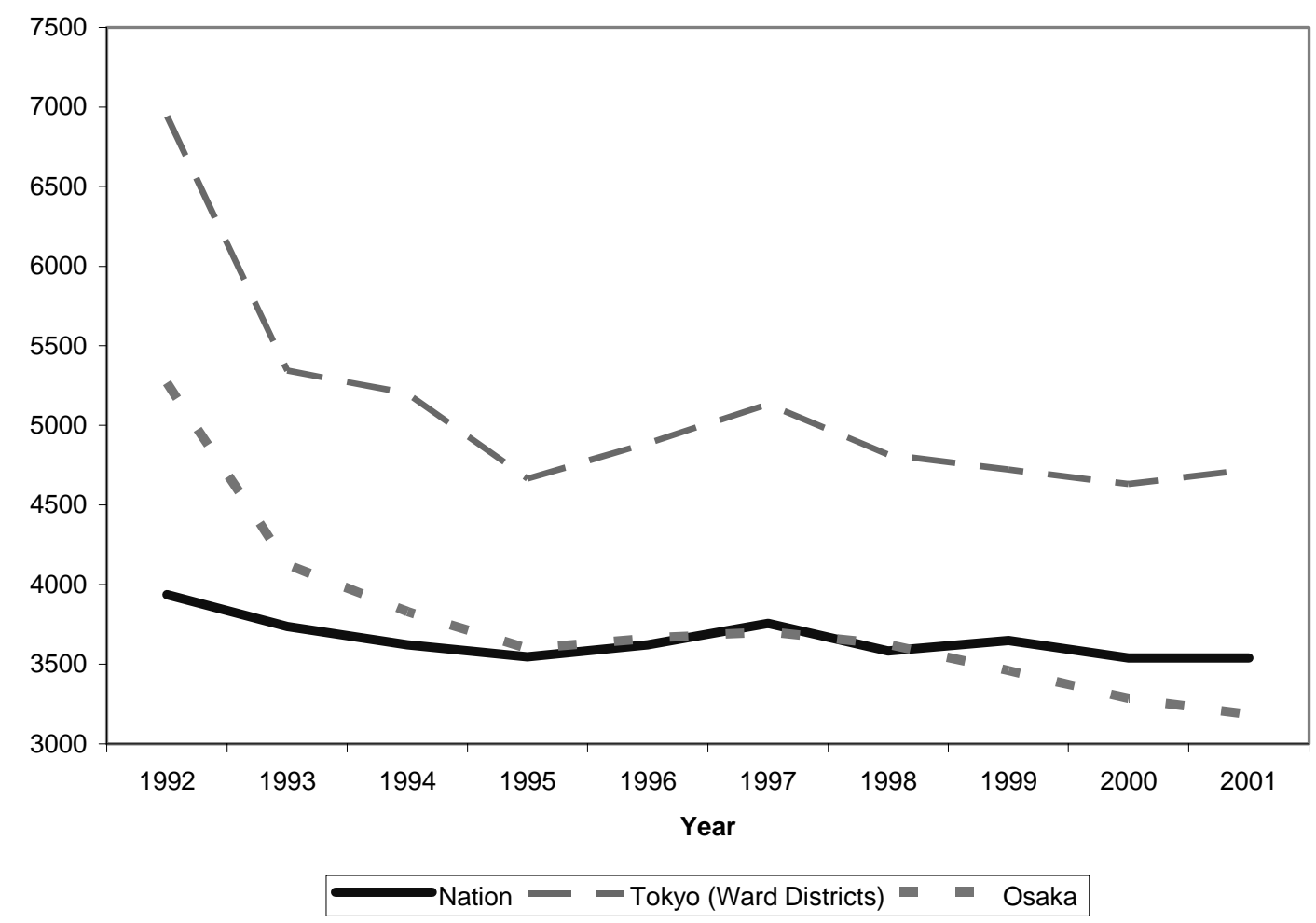

Notes: Figures are in ten-thousand yen. Average prices for condominiums for the nation as a whole, and the Tokyo and Osaka Ward districts. Source: Real Estate Economic Institute (Fudosan-Keizai-Kenkyusho in Japanese). 
Figure 8

\section{Land Price Data}

\section{(1993Q2 - 2003Q1)}

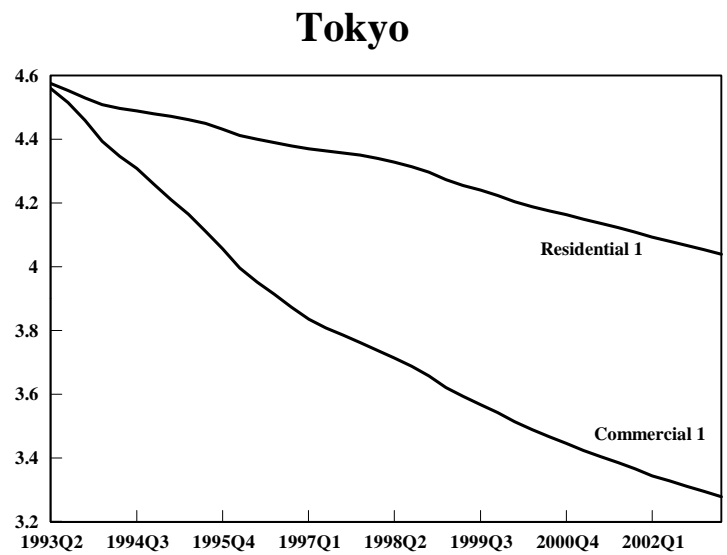

\section{Osaka}

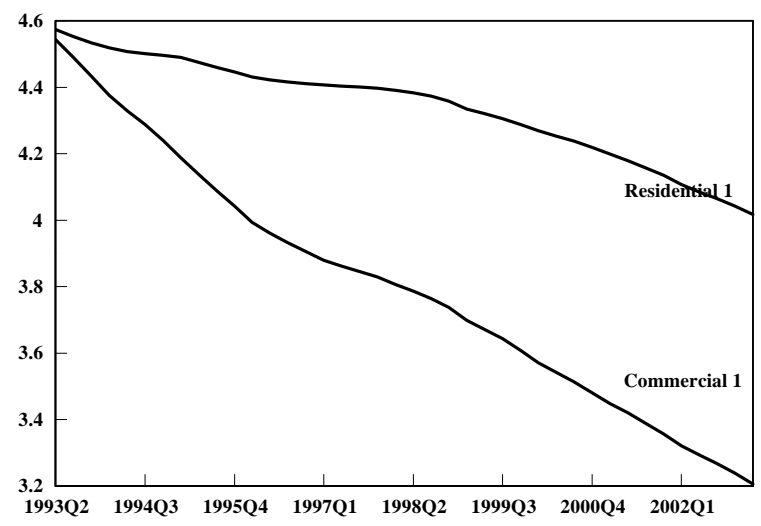

Nagoya

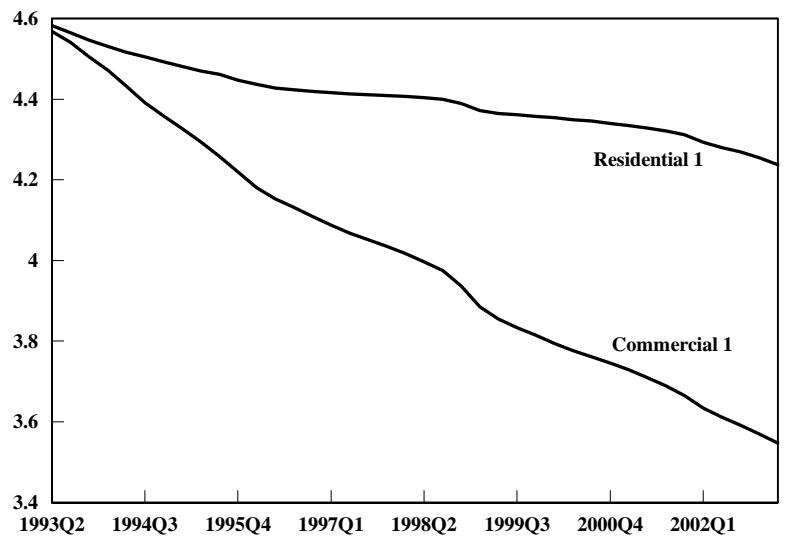

Notes: Figures in logs. Land price data is quarterly from 1993:2 through 2003:1 for Tokyo, Osaka, and Nagoya. 1993:2=100. Source: Land Research Institute. 


\section{Figure 9 \\ Average Prefecture Prices for Japan \\ (1976-2001)}

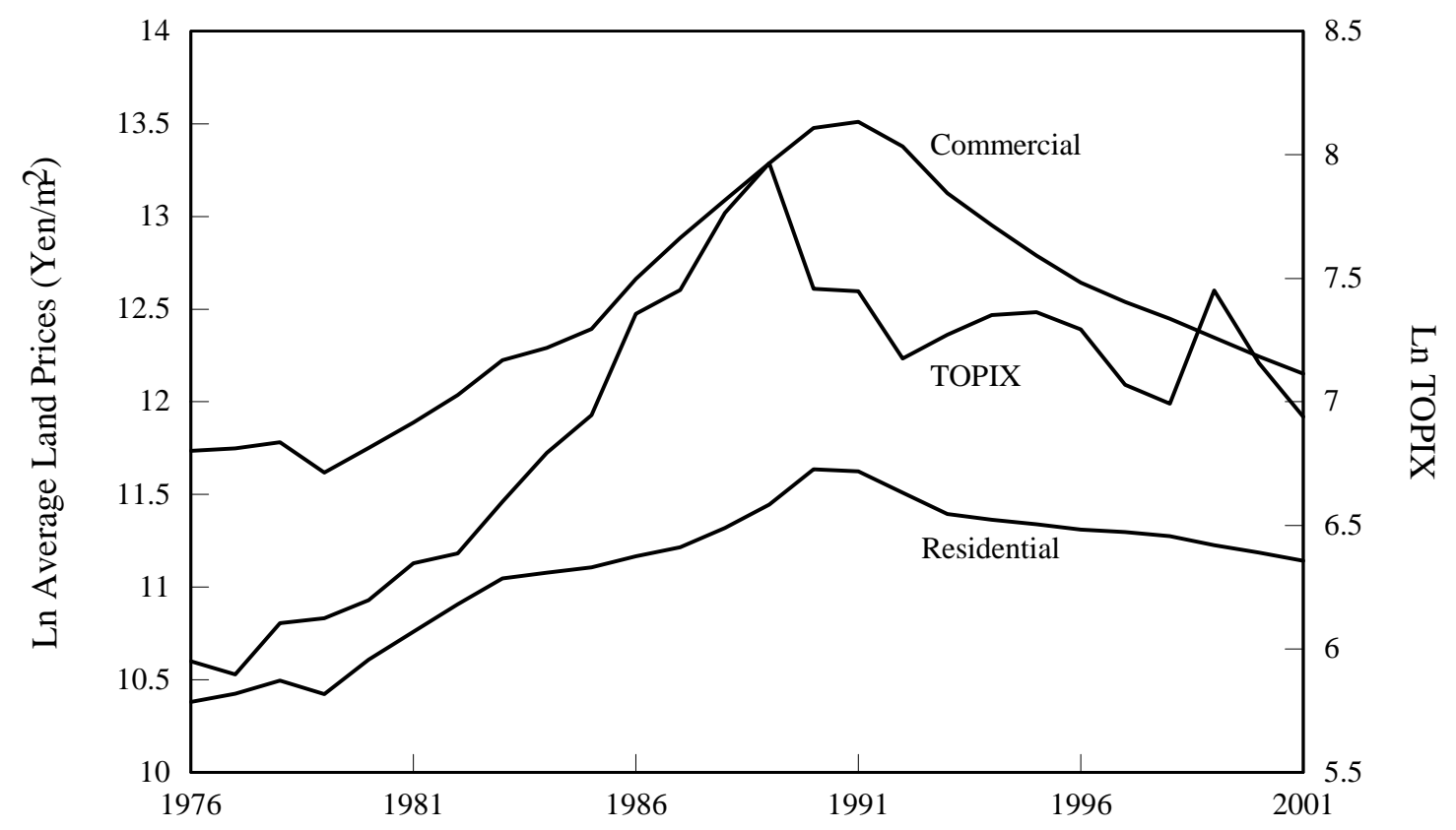

Note: Prices are logarithms of averages of Japanese prefecture data for each year.

Average industrial prices from 1976 to 1978 do not include the Tokushimo prefecture.

Average industrial prices from 1999 to 2001 do not include the Fukui prefecture. Source:

Research on Land Prices by the Prefecture Government. 


\section{Table 1 \\ Real Estate Lending Among Failed Japanese banks}

\begin{tabular}{|l|l|l|c|}
\hline Failed Bank & Failure date & $\begin{array}{l}\text { Real Estate } \\
\text { Company Loans } \\
\text { (million yen) }\end{array}$ & $\begin{array}{l}\text { Percentage share } \\
\text { of real estate } \\
\text { loans }\end{array}$ \\
\hline & & & \\
\hline Hyogo Bank & August 1995 & 355,894 & 16.01 \\
\hline Taiheiyo Bank & April 1996 & 120,306 & 20.62 \\
\hline & & & 23 \\
\hline Tokuyo City Bank & November 1997 & 119,937 & \\
\hline & & & 21.48 \\
\hline Fukutoku Bank & August 1999 & 277,011 & 17.63 \\
\hline & & & 10.67 \\
\hline Tokyo Sowa Bank & June 1999 & 353,879 & \\
\hline & & & \\
\hline Niigata Chuo Bank & October 1999 & 77,000 & \\
\hline & & & \\
\hline
\end{tabular}

Notes: Figures are for March 1990. Table lists Japanese banks that failed during 1990s. August 1999 failure date represents failure of Namihaya Bank. Fukutoku Bank and Naniwa Bank were merged into Namihaya Bank in October 1998, which failed in 1999. The figures in the table are those of Fukutoku Bank in March 1990. 


\section{Table 2 \\ Summary Statistics for Land Prices}

\section{Quarterly Data}

$\begin{array}{lcccccc} & \text { Mean } & \text { Std. Dev. } & \text { Max } & \text { Max Date } & \text { Min } & \text { Min Date } \\ \begin{array}{l}\text { Residential Land Price1 } \\ \text { Tokyo }\end{array} & 75.15 & 11.61 & 97.0 & 1993 \text { Q2 } & 56.75 & \text { 2003 Q1 } \\ \text { Osaka } & 77.52 & 11.39 & 97.0 & 1993 \text { Q2 } & 55.58 & \text { 2003 Q1 } \\ \text { Nagoya } & 81.80 & 7.04 & 97.7 & 1993 \text { Q2 } & 69.26 & \text { 2003 Q1 } \\ \text { Commercial Land Price1 } & & & & & & \\ \text { Tokyo } & 47.52 & 19.62 & 95.5 & 1993 \text { Q2 } & 26.52 & 2003 \text { Q1 } \\ \text { Osaka } & 48.08 & 18.74 & 94.1 & 1993 \text { Q2 } & 24.69 & 2003 \text { Q1 } \\ \text { Nagoya } & 57.53 & 17.74 & 96.4 & 1993 \text { Q2 } & 34.70 & 2003 \text { Q1 }\end{array}$

\section{Prefecture Data}

$\begin{array}{lcccccc} & \text { Mean } & \text { Std. Dev. } & \text { Max } & \text { Max Date } & \text { Min } & \text { Min Date } \\ \text { Residential Land Price } & 70491.33 & 23065.82 & 113168.10 & 1990 & 32204.26 & 1976 \\ \text { Commercial Land Price } & 316588.80 & 190137.10 & 737195.70 & 1991 & 111148.90 & 1979\end{array}$

Notes: Source is Land Research Institute for Quarterly Data and the Research on Land Prices by the Prefecture Government for Annual Prefecture Data. Data for metropolitan areas is quarterly from 1993:2 through 2003:1, while data for prefectures is annual from 1976 through 2001. Max Date and Min Dates are dates corresponding to attainment of max and min values for price data. Source: Land Research Institute. 


\section{Table 3a \\ Error-correction Model results: Quarterly Data Commercial Land Values}

\section{Dependent Variable: $\Delta P_{t}$}

\begin{tabular}{|c|c|c|c|c|c|c|c|}
\hline & 1 & 2 & 3 & 4 & 5 & 6 & 7 \\
\hline Constant & $-0.131^{* *}$ & $0.050^{* *}$ & $-0.042^{* *}$ & $-0.135^{* *}$ & $-0.127^{* *}$ & $-0.050^{* *}$ & $-0.050^{* *}$ \\
& $(0.009)$ & $(0.010)$ & $(0.011)$ & $(0.009)$ & $(0.010)$ & $(0.010)$ & $(0.010)$ \\
\hline$\Delta P_{t-1}$ & - & $0.690^{* *}$ & $0.778^{* *}$ & - & - & $0.692^{* *}$ & $0.690^{* *}$ \\
& & $(0.061)$ & $(0.095)$ & & & $(0.065)$ & $(0.062)$ \\
\hline$\Delta P_{t-2}$ & - & - & -0.080 & - & - & - & - \\
\hline$\Delta$ TOPIX & - & - & - & - & $-0.013^{*}$ & -0.000 & -0.000 \\
& & & & & $(0.090)$ & $(0.005)$ & $(0.005)$ \\
\hline$\Delta$ TOPIX & - & 0.002 & 0.003 & - & - & - & 0.002 \\
& & $(0.006)$ & $(0.006)$ & & & & $(0.006)$ \\
\hline$\Delta$ TOPIX & - & - & 0.002 & - & - & - & - \\
& & & $(0.006)$ & & & & \\
\hline$P_{t-1}-$ TOPIX & $-0.029^{* * 1}$ & $-0.012^{* *}$ & $-0.010^{* *}$ & -0.001 & $-0.028^{* *}$ & $-0.014^{* *}$ & $-0.012^{* *}$ \\
& $(0.003)$ & $(0.003)$ & $(0.003)$ & $(0.007)$ & $(0.003)$ & $(0.005)$ & $(0.003)$ \\
\hline$P_{t-2}-$ TOPIX & - & - & - & $-0.029^{* *}$ & - & 0.002 & - \\
\hline OSAKA & & & & $(0.007)$ & & $(0.006)$ & \\
\hline NAGOYA & -0.001 & -0.000 & -0.000 & -0.001 & -0.001 & -0.000 & -0.000 \\
& $(0.002)$ & $(0.001)$ & $(0.001)$ & $(0.002)$ & $(0.002)$ & $(0.001)$ & $(0.001)$ \\
\hline \# obs & $0.013^{* *}$ & $0.004^{* *}$ & $0.004^{* *}$ & $0.013^{* *}$ & $0.013^{* *}$ & $0.004^{* *}$ & $0.004^{* *}$ \\
& $(0.002)$ & $(0.002)$ & $(0.002)$ & $(0.002)$ & $(0.002)$ & $(0.002)$ & $(0.002)$ \\
\hline $\mathrm{R}^{2}$ & 117 & 114 & 111 & 114 & 117 & 114 & 114 \\
\hline $\mathrm{dp}$ & 0.535 & 0.803 & 0.798 & 0.589 & 0.546 & 0.803 & 0.803 \\
\hline
\end{tabular}

Notes: Estimation by ordinary least squares. See text for model specification. * indicates statistical significance at $10 \%$ confidence level. ** indicates statistical significance at $5 \%$ confidence level. dp represents panel Durbin-Watson statistic. $* *$ indicates null of no serial correlation rejected at five percent confidence level. 


\section{Table 3b \\ Error-correction Model results: Quarterly Data Residential Land Values}

Dependent Variable: $\Delta P_{t}$

\begin{tabular}{|c|c|c|c|c|c|c|c|}
\hline & 1 & 2 & 3 & 4 & 5 & 6 & 7 \\
\hline Constant & $\begin{array}{c}-0.037 * * \\
(0.010)\end{array}$ & $\begin{array}{c}-0.021 * * \\
(0.006)\end{array}$ & $\begin{array}{l}-0.014 * * \\
(0.007)\end{array}$ & $\begin{array}{c}-0.043^{* *} \\
(0.011)\end{array}$ & $\begin{array}{c}-0.033 * * \\
(0.010)\end{array}$ & $\begin{array}{c}-0.022^{* *} \\
(0.007)\end{array}$ & $\begin{array}{l}-0.022 * * \\
(0.007)\end{array}$ \\
\hline$\Delta P_{t-1}$ & - & $\begin{array}{c}0.817 * * \\
(0.055) \\
\end{array}$ & $\begin{array}{l}0.828 * * \\
(0.096)\end{array}$ & - & - & $\begin{array}{c}0.822 * * \\
(0.056) \\
\end{array}$ & $\begin{array}{l}0.819 * * \\
(0.055)\end{array}$ \\
\hline$\Delta P_{t-2}$ & - & - & $\begin{array}{l}-0.019 \\
(0.096) \\
\end{array}$ & - & - & - & - \\
\hline$\Delta T O P I X_{t}$ & - & - & - & - & $\begin{array}{l}-0.008 \\
(0.005)\end{array}$ & $\begin{array}{c}0.001 \\
(0.003)\end{array}$ & $\begin{array}{c}0.001 \\
(0.003)\end{array}$ \\
\hline$\Delta T O P I X_{t-1}$ & - & $\begin{array}{c}0.004 \\
(0.003)\end{array}$ & $\begin{array}{c}0.005 \\
(0.003)\end{array}$ & - & - & - & $\begin{array}{c}0.004 \\
(0.003)\end{array}$ \\
\hline$\Delta T_{O P I X}{ }_{t-2}$ & - & - & $\begin{array}{l}0.007 * * \\
(0.003)\end{array}$ & - & - & - & - \\
\hline$P_{t-1}-$ TOPIX $_{t-1}$ & $\begin{array}{c}-0.008 * * \\
(0.003)\end{array}$ & $\begin{array}{c}-0.007 * * \\
(0.002)\end{array}$ & $\begin{array}{l}-0.004^{*} \\
(0.002)\end{array}$ & $\begin{array}{l}-0.001 \\
(0.005)\end{array}$ & $\begin{array}{l}-0.007 * \\
(0.004)\end{array}$ & $\begin{array}{c}-0.011 * * \\
(0.003)\end{array}$ & $\begin{array}{c}-0.007 * * \\
(0.002)\end{array}$ \\
\hline$P_{t-2}-T_{O P I X}$ & - & - & - & $\begin{array}{l}-0.010^{*} \\
(0.005)\end{array}$ & - & $\begin{array}{c}0.004 \\
(0.003)\end{array}$ & - \\
\hline$O S A K A$ & $\begin{array}{l}-0.000 \\
(0.001) \\
\end{array}$ & $\begin{array}{l}-0.000 \\
(0.001) \\
\end{array}$ & $\begin{array}{l}-0.000 \\
(0.001)\end{array}$ & $\begin{array}{l}-0.000 \\
(0.001) \\
\end{array}$ & $\begin{array}{l}-0.000 \\
(0.001)\end{array}$ & $\begin{array}{l}-0.000 \\
(0.001) \\
\end{array}$ & $\begin{array}{l}-0.000 \\
(0.001)\end{array}$ \\
\hline NAGOYA & $\begin{array}{l}0.006 * * \\
(0.001)\end{array}$ & $\begin{array}{c}0.001 \\
(0.001)\end{array}$ & $\begin{array}{c}0.001 \\
(0.001) \\
\end{array}$ & $\begin{array}{l}0.006^{* *} \\
(0.001)\end{array}$ & $\begin{array}{l}0.006 * * \\
(0.001)\end{array}$ & $\begin{array}{c}0.001 \\
(0.001)\end{array}$ & $\begin{array}{c}0.001 \\
(0.001)\end{array}$ \\
\hline \# obs & 117 & 114 & 111 & 114 & 117 & 114 & 114 \\
\hline $\mathrm{R}^{2}$ & 0.200 & 0.744 & 0.745 & 0.223 & 0.216 & 0.744 & 0.744 \\
\hline $\mathrm{dp}$ & $0.358 * *$ & 1.952 & 1.918 & $0.373 * *$ & $0.382^{* *}$ & 1.949 & 1.949 \\
\hline
\end{tabular}

Notes: Estimation by ordinary least squares. Sample pools data from Tokyo, Nagoya and Osaka metropolitan areas. See text for model specification. * indicates statistical significance at $10 \%$ confidence level. $* *$ indicates statistical significance at $5 \%$ confidence level. dp represents panel Durbin-Watson statistic. ** in dp test indicates null of no serial correlation rejected at five percent confidence level. 


\section{Table 4a \\ Error-correction Model results: Prefecture Data Commercial Land Values}

Dependent Variable: $\Delta P_{t}$

\begin{tabular}{|c|c|c|c|c|c|c|c|}
\hline$\Delta \mathrm{PC}_{\mathrm{t}}$ & 1 & 2 & 3 & 4 & 5 & 6 & 7 \\
\hline $\mathrm{C}$ & $\begin{array}{c}0.605 * * \\
(0.059)\end{array}$ & $\begin{array}{c}0.696 * * \\
(0.057) \\
\end{array}$ & $\begin{array}{c}0.644 * * \\
(0.065)\end{array}$ & $\begin{array}{c}0.848 * * \\
(0.062)\end{array}$ & $\begin{array}{c}0.679 * * \\
(0.059)\end{array}$ & $\begin{array}{c}0.826^{* * *} \\
(0.056)\end{array}$ & $\begin{array}{c}0.826 * * \\
(0.056)\end{array}$ \\
\hline$\Delta \mathrm{PC}_{\mathrm{t}-1}$ & - & $\begin{array}{c}0.488 * * \\
(0.025) \\
\end{array}$ & $\begin{array}{c}0.422 * * \\
(0.028)\end{array}$ & - & - & $\begin{array}{c}0.456 * * \\
(0.030) \\
\end{array}$ & $\begin{array}{c}0.502 * * \\
(0.024)\end{array}$ \\
\hline$\Delta \mathrm{PC}_{\mathrm{t}-2}$ & - & - & $\begin{array}{c}0.098 * * \\
(0.029)\end{array}$ & - & - & 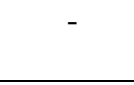 & - \\
\hline$\Delta$ TOPIX $_{t}$ & - & - & - & - & $\begin{array}{c}0.150 * * \\
(0.022)\end{array}$ & $\begin{array}{c}0.184 * * \\
(0.019)\end{array}$ & $\begin{array}{c}0.184 * * \\
(0.019)\end{array}$ \\
\hline$\Delta$ TOPIX $_{\mathrm{t}-1}$ & - & $\begin{array}{c}-0.021 \\
(0.021) \\
\end{array}$ & $\begin{array}{c}0.009 \\
(0.021) \\
\end{array}$ & - & - & - & $\begin{array}{c}-0.045^{* *} \\
(0.020) \\
\end{array}$ \\
\hline$\Delta \mathrm{TOPIX}_{\mathrm{t}-2}$ & - & - & $\begin{array}{c}0.167 * * \\
(0.022) \\
\end{array}$ & - & - & - & - \\
\hline $\begin{array}{c}\mathrm{PC}_{\mathrm{t}-1}- \\
\text { TOPIX }_{\mathrm{t}-1} \\
\end{array}$ & $\begin{array}{c}-0.113^{* *} \\
(0.011) \\
\end{array}$ & $\begin{array}{c}-0.132 * * \\
(0.011)\end{array}$ & $\begin{array}{c}-0.126^{* *} \\
(0.012) \\
\end{array}$ & $\begin{array}{c}0.044 * * \\
(0.019) \\
\end{array}$ & $\begin{array}{c}-0.128 * * \\
(0.011)\end{array}$ & $\begin{array}{c}-0.113^{* * *} \\
(0.019) \\
\end{array}$ & $\begin{array}{c}-0.159 * * \\
(0.011) \\
\end{array}$ \\
\hline $\begin{array}{c}\mathrm{PC}_{\mathrm{t}-2}- \\
\text { TOPIX }_{\mathrm{t}-2} \\
\end{array}$ & - & - & - & $\begin{array}{c}-0.203 * * \\
(0.019) \\
\end{array}$ & - & $\begin{array}{c}-0.045^{* * *} \\
(0.020) \\
\end{array}$ & - \\
\hline \# obs & 1175 & 1128 & 1081 & 1128 & 1175 & 1128 & 1128 \\
\hline $\mathrm{R}^{2}$ & 0.090 & 0.330 & 0.394 & 0.188 & 0.127 & 0.383 & 0.383 \\
\hline $\mathrm{dp}$ & $1.037 * *$ & 2.076 & 1.824 & $1.176^{* *}$ & $1.028 * *$ & 2.121 & 2.121 \\
\hline
\end{tabular}

Notes: Estimation by ordinary least squares. Sample pools data from 47 Japanese prefectures from 1976 through 2001. See text for model specification. * indicates statistical significance at $10 \%$ confidence level. $* *$ indicates statistical significance at $5 \%$ confidence level. 


\section{Table 4b \\ Error-correction Model results: Prefecture Data Residential Land Values}

Dependent Variable: $\Delta P_{t}$

\begin{tabular}{|c|c|c|c|c|c|c|c|}
\hline$\Delta \mathrm{PR}_{\mathrm{t}}$ & 1 & 2 & 3 & 4 & 5 & 6 & 7 \\
\hline $\mathrm{C}$ & $\begin{array}{c}0.115^{* *} \\
(0.033)\end{array}$ & $\begin{array}{c}0.209 * * \\
(0.035) \\
\end{array}$ & $\begin{array}{c}0.197 * * \\
(0.038) \\
\end{array}$ & $\begin{array}{c}0.190 * * \\
(0.036) \\
\end{array}$ & $\begin{array}{c}0.144 * * \\
(0.035) \\
\end{array}$ & $\begin{array}{c}0.277 * * \\
(0.037) \\
\end{array}$ & $\begin{array}{c}0.277 * * \\
(0.037) \\
\end{array}$ \\
\hline$\Delta \mathrm{PR}_{\mathrm{t}-1}$ & - & $\begin{array}{c}0.307 * * \\
(0.030)\end{array}$ & $\begin{array}{c}0.308 * * \\
(0.030)\end{array}$ & - & - & $\begin{array}{c}0.288 * * \\
(0.033)\end{array}$ & $\begin{array}{l}0.328 * * \\
(0.030)\end{array}$ \\
\hline$\Delta \mathrm{PR}_{\mathrm{t}-2}$ & - & - & $\begin{array}{c}0.009 \\
(0.031) \\
\end{array}$ & - & - & - & - \\
\hline$\Delta$ TOPIX $_{t}$ & - & - & - & - & $\begin{array}{c}0.043 * * \\
(0.017)\end{array}$ & $\begin{array}{c}0.083 * * \\
(0.017)\end{array}$ & $\begin{array}{c}0.083 * * \\
(0.017)\end{array}$ \\
\hline$\Delta$ TOPIX $_{\mathrm{t}-1}$ & - & $\begin{array}{l}-0.030^{*} \\
(0.016) \\
\end{array}$ & $\begin{array}{c}-0.018 \\
(0.016) \\
\end{array}$ & - & - & - & $\begin{array}{c}-0.040^{* *} \\
(0.016)\end{array}$ \\
\hline$\Delta$ TOPIX $_{\mathrm{t}-2}$ & - & - & $\begin{array}{c}0.123^{* *} \\
(0.017) \\
\end{array}$ & - & - & - & - \\
\hline $\begin{array}{c}\text { PR }_{\mathrm{t}-1}- \\
\text { TOPIX }_{\mathrm{t}-1}\end{array}$ & $\begin{array}{c}-0.023^{* *} \\
(0.009) \\
\end{array}$ & $\begin{array}{c}-0.049 * * \\
(0.009)\end{array}$ & $\begin{array}{c}-0.049 * * \\
(0.010) \\
\end{array}$ & $\begin{array}{c}0.050^{* *} \\
(0.016)\end{array}$ & $\begin{array}{c}-0.030^{* * *} \\
(0.009)\end{array}$ & $\begin{array}{l}-0.028 \\
(0.017)\end{array}$ & $\begin{array}{c}-0.068^{* *} \\
(0.010) \\
\end{array}$ \\
\hline $\begin{array}{l}\text { PR }_{\mathrm{t}-2}- \\
\text { TOPIX }_{\mathrm{t}-2}\end{array}$ & - & - & - & $\begin{array}{c}-0.092^{* *} \\
(0.015)\end{array}$ & - & $\begin{array}{c}-0.040 * * \\
(0.016)\end{array}$ & - \\
\hline \# obs & 1175 & 1128 & 1081 & 1128 & 1175 & 1128 & 1128 \\
\hline $\mathrm{R}^{2}$ & 0.017 & 0.111 & 0.162 & 0.054 & 0.022 & 0.130 & 0.130 \\
\hline $\mathrm{dp}$ & $1.422 * *$ & 1.978 & 1.730 & 1.489 & $1.404 * *$ & 2.000 & 2.000 \\
\hline
\end{tabular}

Notes: Estimation by ordinary least squares. Sample pools data from 47 Japanese prefectures from 1976 through 2001. See text for model specification. * indicates statistical significance at $10 \%$ confidence level. ** indicates statistical significance at $5 \%$ confidence level. Results of panel dp test for specification 4 fell in inconclusive range. 